\title{
National Courts as Actors in Investment Arbitration
}

\author{
Aniruddha Rajput
}

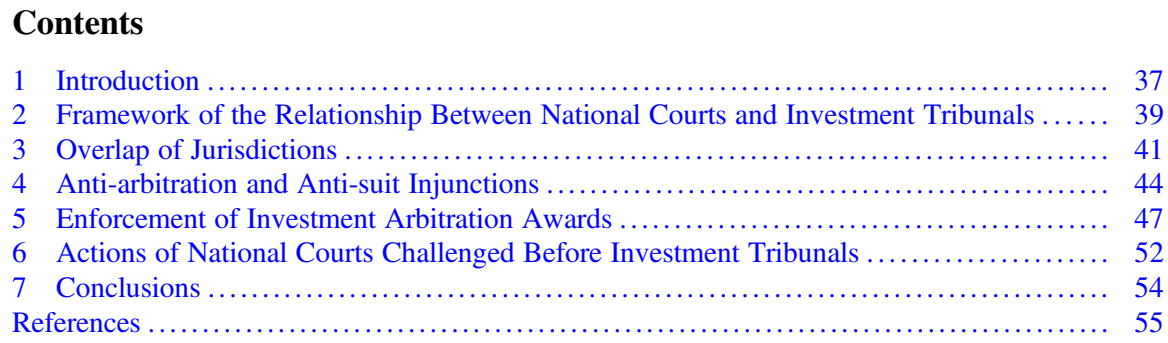

\begin{abstract}
National courts are actors in investment arbitration since they influence the functioning of investment arbitration and are themselves in turn influenced by investment arbitration. The influence of national courts on investment arbitration is larger than the influence of other international courts and tribunals, since national law is part of the applicable law in investment arbitration and national courts are authorised to interpret and apply national law. National courts influence investment arbitration by competing for jurisdiction through the exhaustion of local remedies, umbrella clauses, and the fork-in-the-road rule. National courts facilitate investment arbitration by enforcing awards and at the same time disrupt it when rejecting enforcement or issuing anti-arbitration injunctions. Investment tribunals can restrain national courts by issuing anti-suit injunctions. Above all, they can review the decisions of national courts on grounds of denial of justice, fair and equitable treatment, the effective means test, and indirect expropriation. The the relationship between national courts and investment tribunals is such that the later have the last word, although the role of national courts as actors is certainly noteworthy.
\end{abstract}

\footnotetext{
A. Rajput ( $\bowtie)$

International Law Commission \& Withersworldwide, London, UK 


\section{Introduction}

Legal dictionaries define the term "actor" in diverse ways. An actor is a "person who instigates or is involved in a legal action". 1 The actor may be involved in the legal proceedings as a party ${ }^{2}$ or may be someone whose conduct is in question in the legal proceedings. ${ }^{3}$ Broadly seen, an actor is someone involved in legal proceedings in one way or another. ${ }^{4}$ National courts are actors in investment arbitration. They may be involved directly when their decisions form the basis of a cause of action in investment arbitration proceedings. The activities of national courts may also affect the functioning of investment arbitration. National courts function as actors in investment arbitration by performing distinct roles. They may compete for jurisdiction, act as facilitators of the process and outcome of investment arbitration proceedings, or obstruct the arbitration process and its outcome. It is, therefore, necessary to investigate their role as actors in investment arbitration.

National courts can influence investment arbitration in specific situations or have a systemic influence on the overall functioning of investment arbitration. They can potentially interfere with investment arbitration both at the pre-award stage and at the post-award stage. In the pre-award phase, national courts may issue antiarbitration injunctions or compete for jurisdiction with investment tribunals. In the post-award phase, the award delivered could be enforced or challenged before national courts, except for awards issued under the Convention on the Settlement of Investment Disputes between States and Nationals of Other States (ICSID Convention).

After this introduction, the second section deals with the influence of national courts on the system of investment arbitration by setting out the general framework of the relationship between national courts and investment arbitration. The following sections discuss specific aspects of this influence. The third section discusses the situations and ways in which national courts compete for jurisdiction with investment tribunals. The fourth section shows the actions of national courts as a disruptive force, in the form of anti-arbitration injunctions and counteraction by investment tribunals through anti-suit injunctions. The fifth section presents the ways in which, through recognition and enforcement of investment awards, national courts can either facilitate or destroy the outcome of investment arbitration proceedings. The sixth section elaborates on the situations where actions of national courts form the

\footnotetext{
${ }^{1}$ Oxford English Dictionary Online (2019) Oxford University Press. https://www.oed.com/view/ Entry/1963? redirectedFrom=actors; Bouvier's Law Dictionary, (1856). https://www.constitution. org/bouv/bouvier_a.htm.

${ }^{2}$ Sheppard SM (ed) (2011) The Wolters Kluwer Bouvier Law Dictionary, Compact Edition, p. 32. ${ }^{3}$ Garner BA (ed) (2009) Black's Law Dictionary 10th edition, p. 42; Collins Online English Dictionary (2019) Actor, n. HarperCollins Publishing. https://www.collinsdictionary.com/ dictionary/english/actor.

${ }^{4}$ Burton WC (ed) (1992), Legal Thesaurus, 2nd edition, p. 9.
} 
basis of the subject-matter of a dispute before an investment tribunal. The last section concludes.

\section{Framework of the Relationship Between National Courts and Investment Tribunals}

Traditionally, an international tribunal will treat a decision of a national court as a question of fact. ${ }^{5}$ In practice, this relationship has changed because ever-larger issues of national law are coming before international courts and tribunals and more issues of international law are adjudicated in national courts. ${ }^{6}$

National court decisions contribute towards the formation of customary international law. They may serve as evidence of state practice $^{7}$ or opinio juris $^{8}$ or, in appropriate cases, as proof of the "existence and content of rules of customary international law, as a subsidiary means for the determination of such rules." They are an obvious basis for general principles of law, as a source of international law. ${ }^{10}$ If called upon to determine the existence of a rule of customary international law or general principle of law, an investment tribunal would have to take into account decisions of national courts. Additionally, legal principles contained in the decisions of national courts can be adapted and applied in international adjudication once they go through the process of "abstraction, generalization and adjustment". 11

National courts have a larger influence in investment arbitration proceedings due to the peculiar status of national law as part of the applicable law in investment arbitration proceedings. ${ }^{12}$ Bilateral investment treaties (BITs) do not offer a

\footnotetext{
${ }^{5}$ Certain German Interests in Polish Upper Silesia (Germany v. Poland), Decision on the Merits, (1926) PCIJ Series A.- No. 7, p. 19; Brownlie (2003), pp. 38-40.

${ }^{6}$ Nollkaemper (2006), pp. 301-303, 312-321.

${ }^{7}$ Draft Conclusion 6 (2), Draft conclusions on identification of customary international law. International Law Commission, A/73/10, http://legal.un.org/ilc/texts/instruments/english/draft_ articles/1_13_2018.pdf.

${ }^{8}$ Draft Conclusion 10 (2), Draft conclusions on identification of customary international law. International Law Commission, A/73/10, http://legal.un.org/ilc/texts/instruments/english/draft_ articles/1_13_2018.pdf.

${ }^{9}$ Draft Conclusion 13, Draft conclusions on identification of customary international law. International Law Commission, A/73/10, http://legal.un.org/ilc/texts/instruments/english/draft_articles/1_ 13_2018.pdf.

${ }^{10}$ Case Concerning the Factory at Chorzów (Germany v. Poland), 1927, PCIJ Rep. Series A.No. 9, p. 31; Yotova (2017), p. 298.

${ }^{11}$ Weil (1992), pp. 146-147.

${ }^{12}$ See Article 42 of the ICSID Convention; Canada-Argentina BIT (1993); Argentina-Spain BIT (1991); Canada-Costa Rica BIT (1999). For the role and relevance of national law, see generally Kjos (2013) and Sasson (2017).
} 
hierarchy between national and international law. However, in situations where there is a direct conflict, national law will have to give way. The decisions of national courts are authoritative pronouncements on matters of national law and an investment tribunal will take these decisions into account when interpreting and applying the appropriate national law. ${ }^{13}$

Article 8.31 (2) of the Canada-EU Comprehensive Economic and Trade Agreement (CETA) acknowledges the relevance of decisions of national courts in the following terms:

For greater certainty, in determining the consistency of a measure with this Agreement, the Tribunal may consider, as appropriate, the domestic law of the disputing Party as a matter of fact. In doing so, the Tribunal shall follow the prevailing interpretation given to the domestic law by the courts or authorities of that Party and any meaning given to domestic law by the Tribunal shall not be binding upon the courts or the authorities of that Party.

The provision treats national law as a matter of fact, but in other cases, where such interpretation is not adopted by the parties, national law would continue to operate as 'applicable law', rather than a mere 'matter of fact'. In any event, this provision makes it necessary for an investment tribunal to follow the interpretation of national law as given by national courts. For other treaties, decisions of national courts would be applicable as authoritative pronouncements alongside international law, particularly in common law jurisdictions where the rule of precedent applies.

The role and influence of national courts in investment arbitration is different when compared to commercial arbitration. National courts are an influential actor in commercial arbitration since these proceedings - even if international in nature-are conducted within the context of the national legislation on arbitration. National courts can issue interim orders prior to or even in pending arbitration proceedings, and they can even be involved in the appointment of arbitrators. A commercial arbitral tribunal can seek the support of the national court in relation to the presence of witnesses or procurement of evidence, or other related matters. National courts perform a general supervisory function. They cannot and do not have the same relationship with investment tribunals. Investment arbitration is "delocalised". It draws its authority from a BIT, which is an international treaty, unlike commercial arbitration which is based on a contract between the parties and national arbitration legislation recognising the arbitration proceedings and their outcome. Analogies with the relationship of national courts with international commercial arbitration for the purpose of investment arbitration is unhelpful.

${ }^{13}$ Malicorp Limited v. Egypt, ICSID Case No. ARB/08/18, para. 103 (c). 


\section{Overlap of Jurisdictions}

National courts function as actors in investment arbitration through competition for jurisdiction. The outcome of this competition may fully or partially deprive, either the national court or the investment tribunal of its jurisdiction. The overlap of jurisdiction may arise in the application of the following rules: exhaustion of local remedies, contractual versus treaty claims, umbrella clauses, and fork-in-the-road clauses.

The jurisdiction of national courts is preserved through the exhaustion of local remedies rule in the BIT. Some treaties provide for an absolute exhaustion of the local remedies rule, whereby an investor cannot commence investment arbitration until a final decision is rendered by national courts. ${ }^{14}$ Some other BITs require local remedies to be pursued for a certain duration before initiating arbitration proceedings. ${ }^{15}$ Some investment tribunals have ignored the exhaustion of local remedies rule, where local remedies would be futile. ${ }^{16}$ If an investment tribunal upholds the exhaustion of the local remedies rule, the jurisdiction of national courts would run its full course, even dispensing with the need of an investment arbitration proceeding. But if an investment tribunal does not uphold the exhaustion of local remedies rule, the tribunal would be depriving national courts of their jurisdiction.

Investment disputes are complex and involve several issues. Some of these issues may overlap with the jurisdiction of national courts or a contractually chosen forum, thereby creating the overlap between contractual and treaty claims. Strictly speaking, disputes arising from contractual relationships can be distinguished from disputes arising from the breach of the BIT. The contractual disputes could be decided by a national court or a contractually chosen forum, which would normally seek support and protection from a national court. Whereas, the disputes arising from the breach of the BIT could be decided by an investment tribunal. The dichotomy of this jurisdiction was recognised by the ad hoc annulment committee in Vivendi v. Argentina in the following words:

whether there has been a breach of the BIT and whether there has been a breach of contract are different questions. Each of these claims will be determined by reference to its own proper or applicable law-in the case of the BIT, by international law; in the case of the [contract], by the proper law of the contract, in other words, the [national law]. ${ }^{17}$

\footnotetext{
${ }^{14}$ Article 10(5) of the Gemany-Israel BIT; Article 7(2) of the Romania-Sri Lanka BIT.

${ }^{15}$ Article 8(2) of the Albania-Lithuania BIT; Article 10 of the France-Morocco BIT; Article 8(3)(4) of the Jordan- Romania BIT; Article 9(3) of the China-Côte d'Ivoire BIT; Article 15 (2) of the Indian Model BIT of 2015.

${ }^{16}$ Lowen Group v. United States, ICSID Case No. ARB(AF)/98/3, Award, 26 June 2003, para. 169; Urbaiser v. Argentina, ICSID Case No. ARB/07/26, Decision on Jurisdiction, 19 December 2012, paras 194, 202-3; Ambiente Ufficio v. Argentina, ICSID Case No. ARB/08/9, Decision on Jurisdiction, 8 February 2013, paras 597, 601-11, 615-21; İçkale İnşaat Limited Şirketi v. Turkmenistan, ICSID Case No. ARB/10/24, Award, 8 March 2016, para. 260.

${ }^{17}$ Vivendi v. Argentina, ICSID Case No. ARB/97/3, Decision on Annulment, 3 July 2002, para. 96.
} 
The presence of a contractual clause does not exclude the jurisdiction of an investment tribunal to decide investment disputes. ${ }^{18}$ However, the reverse is not always true. There is a disparity between the jurisdiction exercised by national courts and investment tribunals with the latter having the upper hand-not only do they have broader jurisdiction but they can also decide which aspects of the dispute to retain.

Despite the possibility of parallel proceedings before national courts and investment tribunals deciding different aspects of the same dispute, investment tribunals take over the entire dispute. Investment tribunals have achieved this through an expansive interpretation of 'umbrella clauses'. The debate about the precise scope and interpretation of umbrella clauses and the possibility of investment tribunals having jurisdiction over contractual disputes played out in the SGS v. Pakistan and $S G S$ v. Philippines cases. In SGS v. Pakistan, the tribunal distinguished between contractual and treaty rights and declared that it would not entertain contractual disputes, leaving these to be decided by the arbitral tribunal chosen by contract. ${ }^{19}$ Additionally, the contractual disputes would not be converted into investment disputes through the umbrella clause. ${ }^{20}$ The tribunal in SGS v. Philippines disagreed and criticised the conclusions in SGS v. Pakistan. ${ }^{21}$ The tribunal recognised the distinction between contractual obligations and treaty obligations and did not agree that contractual obligations are converted into treaty obligations through an umbrella clause. $^{22}$ The tribunal in SGS v. Philippines found that the institution of arbitration was premature and the investor ought first to approach the local courts to adjudicate the contractual disputes. ${ }^{23}$ If such an approach is adopted, then the jurisdiction of national courts is conserved. But the debate is far from over and all depends on the approach a particular tribunal takes.

Some tribunals have decided that umbrella clauses can transform contractual disputes into treaty disputes. ${ }^{24}$ Several others have interpreted umbrella clauses in

\footnotetext{
${ }^{18}$ Vivendi v. Argentina, ICSID Case No. ARB/97/3, Decision on Annulment, 3 July 2002, para. 98. ${ }^{19}$ SGS Société Générale de Surveillance SA v. Pakistan, ICSID Case No. ARB/01/13, Decision on Jurisdiction, 6 August 2003, paras 156-62.

${ }^{20}$ SGS Société Générale de Surveillance SA v. Pakistan, ICSID Case No. ARB/01/13, Decision on Jurisdiction, 6 August 2003, paras 163-74.

${ }^{21}$ SGS Société Générale de Surveillance SA v. Philippines, ICSID Case No. ARB/02/6, Decision of the Tribunal on Objections to Jurisdiction, 29 January 2004, paras 121-7.

${ }^{22}$ SGS Société Générale de Surveillance SA v. Philippines, ICSID Case No. ARB/02/6, Decision of the Tribunal on Objections to Jurisdiction, 29 January 2004, para. 128; Joy Mining Mach., Ltd. v. Egypt, ICSID Case No. ARB/03/11, Award on Jurisdiction, 6 August 2004, 13 ICSID Rep. 123 (2008), para. 81.

${ }^{23}$ SGS Société Générale de Surveillance SA v. Philippines, ICSID Case No. ARB/02/6, Decision of the Tribunal on Objections to Jurisdiction, 29 January 2004, para. 155.

${ }^{24}$ Bosh International v. Ukraine, ICSID Case No. ARB/08/I 1, Award, 25 October 2012, para. 252; BIVAC BV v. Paraguay, ICSID Case No. ARB/07/9, Decision of the Tribunal on Objections to Jurisdiction, 29 May 2009, para. 142; LG\&E Energy Corp. v. Argentina, ICSID Case No. ARB/02/ 1, Decision on Liability, 3 October 2006, para. 171.
} 
a manner that does not include violation of contractual provisions, unless there was a breach of treaty provisions. ${ }^{25}$ If the breach of a contractual clause is proved to amount to a treaty breach then the investment tribunal will have jurisdiction. In situations where tribunals have taken one these approaches; the jurisdiction of national courts is excluded.

Some tribunals have adopted a narrow interpretation of umbrella clauses. They have declined jurisdiction over contractual disputes through expansive interpretation of umbrella clauses. ${ }^{26}$ In these situations, the jurisdiction of national courts remains intact.

The nature of the cause of action before a national court or investment tribunal differs since the right to bring a claim would be based either on a contract or a BIT, although, the underlying transaction in many cases is the same. Yet, investment tribunals normally decide which aspects of the dispute they wish to retain and leave the rest for national courts or a contractually chosen forum. Umbrella clauses are losing their lustre since recent treaty practice shows the reluctance of states to include them in their BITs. This reduces the prospect of investment tribunals taking over contractual disputes that would fall within the jurisdiction of national courts.

Fork-in-the-road provisions, if applied, exclude the jurisdiction of an investment tribunal if the governmental action that forms the basis of an investment claim is litigated before national courts. Fork-in-the-road provisions allow the investor to choose whether to sue the host state before national courts or initiate investment arbitration. Once an investor decides to sue the host state before national courts, investment arbitration can no longer be commenced. Fork-in-the-road provisions can be invoked only if the parties to the dispute, the cause of action and the relief sought are the same. ${ }^{27}$ These requirements are often not met, since the party sued in national courts under a contract may be a state entity and the host state may not be a party to these proceedings. Likewise, the cause of action in national courts would arise from a contract whereas in investment arbitration from a BIT.

A foreign investor has to establish itself in a host state and function in accordance with its laws. National courts are the default judicial institutions with jurisdiction

\footnotetext{
${ }^{25}$ Eureko BV v. Poland, Partial Award, 19 August 2005), 12 ICSID Rep. 335 (2007), para. 260; Sempra Energy International v. Argentina, ICSID Case No. ARB/02/16, Award, 28 September 2007, para. 310; El Paso Energy International Company v. Argentina, ICSID Case No. ARB/03/15, Decision on Jurisdiction, 27 April 2006, para. 82.

${ }^{26}$ Impregilo SpA v. Pakistan, ICSID Case No. ARB/03/3, Decision on Jurisdiction, 22 April 2005, para. 216; Toto Costruzioni Generali v. Lebanon, ICSID Case No. ARB/07/12, Decision on Jurisdiction, 11 September 2009, para. 202; Joy Mining Mach., Ltd. v. Egypt, ICSID Case No. ARB/03/1 1, Award on Jurisdiction, 6 August 2004, 13 ICSID Rep. 123 (2008); Vivendi v. Argentina, Case No. ARB/97/3, Decision on Annulment, 3 July 2002, 8 ICSID Rep. 490 (2005), para. 101.

${ }^{27}$ Pantechniki SA Contractors \& Engineers (Greece) v. Albania, ICSID Case No. ARB/07/21, Award, July 29, 2009; Total SA v. Argentina, ICSID Case No. ARB/04/1, Decision on Liability, 27 December 2010, para. 1443; Toto Costruzioni Generali v. Lebanon, ICSID Case No. ARB/07/ 12, Decision on Jurisdiction, 11 September 2009, para. 203; H\&H Enters. Invs., Inc. v. Egypt, ICSID Case No. ARB/09/15, Award, 6 May 2014.
} 
over investment activity within the host state. In the absence of an investment treaty, a foreign investor would have to approach national courts in the event of a dispute. The compulsory dispute resolution clause in an investment treaty excludes the otherwise default jurisdiction of national courts. There is thus an overlap as well as a close relation between national courts and investment tribunals. The ultimate winner of the contest for jurisdiction depends on the language of the BIT and, ultimately, on the approach that an investment tribunal will adopt.

A national court may assert jurisdiction through the principles discussed above. However, the outcome of this contest for jurisdiction is mostly decided by investment tribunals, since these issues tend to be raised before them. The only opportunity national courts have is to review the decisions of investment tribunals at the enforcement stage. National courts could then examine whether the assumption of jurisdiction was proper. In most cases, the national court where enforcement of an investment award is sought would not be the same court that was deprived of its jurisdiction. It could very well be a national court of another state, which may or may not be sympathetic to another national court on account of its loss of jurisdiction. Additionally, the national court where enforcement proceedings take place would have its own standards to apply, which may or may not take into account the fact that the jurisdiction of another national court was taken over by the investment tribunal.

National courts could hardly be said to be an organised force, like investment tribunals. Arbitrations conducted within the framework of the International Centre for Settlement of Investment Disputes (ICSID) function in a certain environment and culture. Although they do not have any formal relation to each other, they are said to have a common public policy objective. ${ }^{28}$ There are several connecting factors between investment tribunals, such as repeat arbitrator appointments and reliance by tribunals on each other's decisions. National courts rarely deal with issues arising from international investment law and have no occasion or interest to function in an organised manner. This inevitably puts arbitral tribunals ahead in the race with little or no prospects for the national courts to assert jurisdiction. In addition, national courts have a heavy caseload of their own and have little incentive to enter such a competition.

\section{Anti-arbitration and Anti-suit Injunctions}

National courts can act as a disruptive force for pending or ongoing investment arbitration proceedings by issuing anti-arbitration injunctions. Likewise, an investment tribunal can issue an anti-suit injunction. An anti-arbitration injunction is an order issued by the national court directing an investment tribunal to halt the arbitration proceeding or the parties to not pursue the arbitration. An anti-suit injunction is an order by an investment tribunal almost always addressed to the

${ }^{28}$ Schreuer (2009), pp. 4-5. 
parties and directing them not to commence or not to pursue proceedings parallel to the arbitration before national courts. An anti-suit or anti-arbitration injunction is issued on the premise that a decision-maker has an "inherent power to protect its own jurisdiction in cases where the risk of inconsistent decisions in parallel or duplicate proceedings instituted in other fora have rendered this necessary." 29

Whether national courts are able to act in relation to investment arbitration proceedings depends on whether they follow the practice of issuing anti-arbitration injunctions and on what grounds. Anti-arbitration injunctions are not governed by international law and there is no standard provided by international law. The latter is developed within the domestic legal system. Thus, the practice on issuance of anti-arbitration injunctions differs between national jurisdictions. Even national legislations on arbitration normally do not contain provisions on anti-arbitration injunctions. National courts that issue anti-arbitration injunctions have considered the authority to issue them to emanate from their inherent powers. ${ }^{30}$

If national laws, expressly or impliedly, allow the issuance of anti-arbitration injunctions, a discussion on their appropriateness remains of theoretical value. A practical approach would be to identify and scrutinise the grounds for issuing an antiarbitration injunction. The grounds, scope of their interpretation (whether broad or narrow), and the frequency of their issuance would determine the extent to which a certain national court can affect investment arbitration proceedings. Even where anti-arbitration injunctions are issued, the extent of influence national courts may exert on arbitration proceedings will depend on the depth and persuasiveness of their reasoning and that of the reasoning of an investment tribunal declining to follow that anti-arbitration injunction. Some national courts do not issue anti-arbitration injunctions. ${ }^{31}$ Others issue them on the basis of narrow grounds. ${ }^{32}$

\footnotetext{
${ }^{29}$ Paul Donin de Rosiere v. Iran, Award No. ITM 64-498-1, (1986) 13 Iran-US Claims Tribunal 193, 194.

${ }^{30}$ Sana Hassib Sabbagh v. Wael Said Khoury, [2019] EWCA Civ 1219 (United Kingdom); South Carolina Insurance Co v. Assurantie Maatshappij De Zeven Provincien NV [1987] AC 24 (United Kingdom); Union of India v. Vodafone Plc. and Anr., 2018 SCC Online Del 8842 (India).

${ }^{31}$ Switzerland does not permit anti-arbitration injunctions being issued by national courts, $\operatorname{Air}(P T Y)$ Ltd v. International Air Transport Association, Tribunal de Première Instance 2 May 2005, Case No. c/1043/2005-15 SP, translated in (2005) 23 ASA Bulletin 739, 739.

${ }^{32}$ In India, the courts have "the jurisdiction to restrain international treaty arbitrations which are oppressive, vexatious, inequitable or constitute an abuse of the legal process", Vodafone International Holdings BV v. Government of India [I], PCA Case No. 2016-35, Judgment of the High Court of Delhi Vacating Order of 22 August 2017, 7 May 2018, para. 104; In the United Kingdom, the criteria to be met are: (1) the court has jurisdiction; (2) the discretion can be exercised if (a) the injunction does not cause injustice, (b) the continuation of arbitration would be oppressive, vexatious, unconscionable or an abuse of process; (3) the discretion should be used sparingly and (4) delay would be material, if not fatal to the application, J Jarvis \& Sons Ltd. v. Blue Circle Dartford Estates Ltd, [2007] EWHC (TCC) 1262, para. 40. US courts apply the so-called "China Trading Test": (1) the court must have jurisdiction, (2) parties must be the same and (3) the decision in the action before the court issuing the injunction must dispose of the foreign court or tribunal proceedings, China Trade and Dev Corp. v. Yong 837 F.2d 33, 36-7. In France, an anti-arbitration injunction may be issued only if the arbitration agreement is manifestly null and void and this is
} 
A national court's potential to influence investment arbitration proceedings depends not only on whether it can issue an anti-arbitration injunction, but also on whether that injunction will be respected. Some investment tribunals have proceeded with the dispute without being perturbed by an anti-arbitration injunction. ${ }^{33}$ In such cases, national courts may be ineffective actors.

An arbitral tribunal may issue an anti-suit injunction preventing a party from commencing proceedings before national courts. ${ }^{34}$ These are interim orders aimed at preserving the jurisdiction of the arbitral tribunal. ${ }^{35}$ Like investment tribunals disregarding anti-arbitration injunctions, a national court may disregard an antisuit injunction. In Chevron v. Ecuador, the tribunal issued an interim order directing the state to ensure that the national court did not proceed with the case. ${ }^{36}$ The national court proceeded despite the interim order and concluded the case. The tribunal found that to be a violation of its order and directed the state to compensate the investor. ${ }^{37}$ The tribunal reasoned that the proceedings were unjust, although the parties to the proceedings in the national court were not the same as the disputing parties before the tribunal. ${ }^{38}$

National courts may also issue anti-suit injunctions restraining a party from approaching national courts and directing it to participate in arbitration proceedings. Such examples are probably absent but are nevertheless a possibility. ${ }^{39}$ On such occasions, the concerned national court would be a facilitator of investment arbitration.

raised by one of the parties, Article 1458 of the French New Code of Civil Procedure. In Sweden, an anti-arbitration injunction may be issued only if the validity of the arbitration agreement is in question. See New Arbitration Regime in Sweden (1999), World Arbitration \& Mediation Report 154 (10), pp. 154-155.

${ }^{33}$ Southern Pacific Properties (Middle East) Limited v. Egypt, ICSID Case No. ARB/84/3, Decision on Jurisdiction II, 14 April 1988, para. 60; Hussein Nuaman Soufraki v. United Arab Emirates, ICSID Case No. ARB/02/7, Award, 7 July 2004, para. 55; Hussein Nuaman Soufraki v. United Arab Emirates, ICSID Case No. ARB/02/7, Decision on Annulment, 5 July 2007, paras 59, 78; Saipem SpA v. Bangladesh, ICSID Case No. ARB/05/07, Decision on Jurisdiction and Interim Measures, 21 March 2007, paras 31, 68; Saipem SpA v. Bangladesh, ICSID Case No. ARB/05/07, Award, 30 June 2009, SGS Société Générale de Surveillance SA v. Pakistan, Procedural Order No. 2, 16 October 2002, 8 ICSID Reports 293, pp. 298, 305.

${ }^{34}$ SGS Société Générale de Surveillance SA v. Pakistan, Procedural Order No. 2, 16 October 2002, 8 ICSID Reports 293, p. 305.

${ }^{35}$ Articles $17(2)(b), 17 \mathrm{H} \& 17 \mathrm{I}$ of the UNCITRAL Model Law on International Commercial Arbitration, UN doc A/61/17, Annex 1. For a review of decisions of ICSID tribunals, see Gill (2009), pp. 553-564.

${ }^{36}$ Chevron Corporation and Texaco Petroleum Corporation v. Ecuador, UNCITRAL, Order for Interim Measures, 9 February 2011.

${ }^{37}$ Chevron Corporation and Texaco Petroleum Corporation v. Ecuador, UNCITRAL, Second Partial Award on Track II, 30 August 2018, para. 9.17.

${ }^{38}$ Chevron Corporation and Texaco Petroleum Corporation v. Ecuador, UNCITRAL, Second Partial Award on Track II, 30 August 2018, para. 9.16.

${ }^{39}$ See Rozas (2005), pp. $79-80$. 
There is a difference in attitudes towards anti-arbitration and anti-suit injunctions. An anti-arbitration injunction is frowned upon and seen as unnecessary interference with the arbitration proceedings, whereas an anti-suit injunction is looked upon favourably in academic discourse. ${ }^{40}$ This asymmetry expects national courts to perform a limited role in comparison with investment tribunals, while exercising similar powers. In practice, the situation is divergent and context-specific.

\section{Enforcement of Investment Arbitration Awards}

National courts have the most critical role at the stage of enforcement of investment awards. While they can facilitate investment arbitration by enforcing awards, they can also defeat arbitration by declining enforcement. A non-ICSID Convention award would have to be enforced in a national jurisdiction. There are three aspects of enforcement that are discussed in this section: recognition, enforcement, and challenge. In the process of recognition, a national court is approached by the winning party to seek endorsement of the award; enforcement involves undertaking actual steps to enforce the award; and in the case of a challenge, the losing party seeks the set-aside of the award. ${ }^{41}$ In all three instances (collectively referred to as 'enforcement' for convenience), national courts influence investment arbitration since they determine the fate of the outcome of the arbitration proceedings. National courts may uphold or set aside the award. An award may be challenged by a host state or a foreign investor, where the investment tribunal has dismissed a claim. ${ }^{42}$

An ICSID Convention award is self-executing since it is treated as the decision of the highest court of each state party to the Convention. ${ }^{43}$ Arguments have been advanced that the grounds applicable to review and set-aside of a judgment of the highest court will apply to an ICSID award. ${ }^{44}$ This opens the possibility of a challenge of an ICSID arbitration award before a national court, albeit on limited

\footnotetext{
${ }^{40}$ Schwebel (2005), p. 13; Lew (2008), p. 287.

${ }^{41}$ Harisankar (2015).

${ }^{42}$ See Petrobart Ltd v. Kyrgyz Republic, Judgment of the Supreme Court of 28 March 2008, Case No. 2113-06; Bayview Irrigation District \# 11 and others v. Mexico, Ontario Superior Court, Judicial Review 07-CV-340139-PD2, Judgment of 5 May 2008.

${ }^{43}$ Article 54 (1) of the ICSID Convention.

${ }^{44}$ Letter of Argentina, dated 7 April 2008 cited in: Letter from United States Department of State to Ms Claudia Frutos-Peterson, Secretary of the ad hoc Committee (Siemens), 1 May 2008, https:// www.italaw.com/documents/Siemens-USsubmission.pdf. In the reply to the letter of the United States, Argentina acknowledged that the ICSID setup was different from that of other arbitration rules and it did not allow the award to be refused enforcement on the grounds mentioned in the New York Convention. However, Argentina argued that "the State i.e. the award debtor is to subject compliance with ICSID awards to the same or substantially the same procedures that are applicable to compliance with final judgments of local courts against the States". Argentina also referred to a US District Court decision which had "altered" the award rendered by the tribunal by granting postaward interest. https://www.italaw.com/sites/default/files/case-documents/ita0793.pdf.
} 
grounds. Additionally, in the light of sovereign immunity, there may be occasions when national courts decline enforcement of an ICSID award. ${ }^{45}$ In non-ICSID Convention arbitrations, recognition and enforcement take place according to the Convention on the Recognition and Enforcement of Foreign Arbitral Awards (New York Convention), thereby making national courts prominent actors.

National courts have preserved their jurisdiction to entertain enforcement proceedings of investment arbitration awards under the New York Convention. They have treated investment arbitration awards as arising out of a commercial relationship to allow them to exercise jurisdiction. ${ }^{46}$ The New York Convention does not specify which national court will have jurisdiction to recognise or enforce an award. It is normally presumed that it will be the national court of the seat of arbitration. This is because Article V(1)(a) of the New York Convention stipulates that an award could be set aside if the arbitration agreement is not valid "under the law where the award was made". The same provision also states that an award would not be enforced if the arbitration agreement were "not valid under the law to which the parties have subjected it". Therefore, even the national court whose laws apply to the substance of the dispute is a relevant jurisdiction. Since the national law of the host state is applicable, the recognition or enforcement of an investment arbitration award can be challenged before its national courts. ${ }^{47}$ Additionally, all those jurisdictions where the assets of the losing party (normally the host state) are located are relevant jurisdictions for enforcement, thereby making multiple national courts potential actors.

The enforcement proceedings are brought under the relevant national legislation on arbitration, which incorporates and implements the New York Convention. In Ecuador v. Occidental, the UK courts rejected the investor's argument of "nonjusticiability", according to which the investor had objected to the institution of proceedings in the UK courts on the ground that it would involve interpretation of laws and actions of another sovereign. ${ }^{48}$ The investor had alleged that since the challenge would involve interpretation of international law, the proceedings were non-justiciable. The court rejected the argument on the basis that although the interpretation of international law was non-justiciable, these proceedings related to the rights of a municipal entity, i.e. a foreign investor, and would therefore be subject

\footnotetext{
${ }^{45}$ Blue Ridge Investments, L.L.C. v. Argentina, 902 F. Supp. 2d 367 (SDNY 2012) (United States); Benvenuti \& Bonfant Ltd. v. Banque Commerciale Congolaise and others, Judgment of July 21, 1987, Cour de Cassation, 115 Journal du Droit Interational 108 (1988) (France); AIG Capital Partners v. Kazakhastan, [2005] EWHC 2239 (Comm.) (United Kingdom).

${ }^{46}$ Mexico v. Metaclad, Judgment of the Supreme Court of British Columbia, 2 May 2001, para. 44; Mexico v. Feldman Karpa, Canada, Ontario Court of Appeal, 11 January 2005, para. 41; Czech Republic v. CME Czech Republic BV, Sweden, Seva Court of Appeal, 15 May 2003, 9 ICSID Reports 439, 493; BG Group PLC v. Argentina, US Supreme Court, CASE No. US 12-138 (2014), pp. 6-8.

${ }^{47}$ Blackaby et al. (2015), p. 614.

${ }^{48}$ Ecuador v. Occidental Exploration and Production Company, Judgment, 29 April 2005, EWHC 774 , para. 30 .
} 
to control under the municipal arbitration laws of the seat of arbitration. ${ }^{49}$ National courts have accepted the jurisdiction to entertain a challenge to an investment arbitration award under their domestic law if the seat of the arbitration was in their country. The presence of a sovereign state and the fact that international law was the law applicable to the dispute would not amount to a sufficient ground to decline jurisdiction. ${ }^{50}$ Presence of a foreign investor, i.e. an entity subject to national laws, has been considered to be a sufficient basis to review an investment award under national arbitration laws. ${ }^{51}$ To tackle objections to jurisdiction, national courts have applied doctrines peculiar to their national system. The Stockholm District Court used its national procedural law doctrine of assertion to affirm that the statements made by the claimant fell within the scope of the arbitral tribunal. ${ }^{52}$ Reliance on national laws and particularly national procedural laws and enforcement regimes under the New York Convention expand the role of national courts.

The enforcement proceedings are like any other national proceedings even though they have an international element in the subject-matter of the dispute. The extent of involvement of a national court depends on the grounds for interference with enforcement, as contained in the domestic law. Prominent grounds for declining enforcement of an award are the invalidity of the arbitration agreement, ${ }^{53}$ excess of jurisdiction, ${ }^{54}$ non-arbitrability, ${ }^{55}$ and public policy. ${ }^{56}$ National courts retain the discretion to interpret and apply such grounds.

Host states challenge awards on the ground that the tribunal lacked jurisdiction to decide the dispute or that it exceeded its jurisdiction. ${ }^{57}$ National courts make their own assessment of correctness of the finding of an investment tribunal on jurisdiction. ${ }^{58}$ National courts would interfere and set aside an award fully or partially, if

\footnotetext{
${ }^{49}$ Ecuador v. Occidental Exploration and Production Company, Judgment, 29 April 2005, EWHC 774, paras 73-76. The decision was upheld by the Court of Appeal, Judgment of Court of Appeal, 4 July 2007, EWCA Civ 656.

${ }^{50}$ Russian Federation v. Sedelmayer, Judgment of Stockholm District Court, 12 December 2002, Case No. T6-583-98, (English translation in 2 Stockholm International Arbitration Review (2005)), p. 16.

${ }^{51}$ Russian Federation v. Sedelmayer, Judgment of Stockholm District Court, 12 December 2002, Case No. T6-583-98, (English translation in 2 Stockholm International Arbitration Review (2005)), p. 16.

${ }^{52}$ Russian Federation v. Sedelmayer, Judgment of Stockholm District Court, 12 December 2002, Case No. T6-583-98, (English translation in 2 Stockholm International Arbitration Review (2005)), p. 17.

${ }^{53}$ Article V(1)(a) of the New York Convention.

${ }^{54}$ Article $\mathrm{V}(1)(\mathrm{c})$ of the New York Convention.

${ }^{55}$ Article V(2)(a) of the New York Convention.

${ }^{56}$ Article $\mathrm{V}(2)(\mathrm{b})$ of the New York Convention.

${ }^{57}$ Czech Republic v. Saluka Investments BV, Judgment of the Federal Court of Switzerland, 7 September 2006.

${ }^{58}$ Poland v. Saar Papier Vertriebs GmbH, Swiss Federal Court, 20 September 2000, para. 4.b (paraphrased translation in Hobér and Eliasson (2010), p. 640).
} 
there is excess of jurisdiction. ${ }^{59}$ In Mexico v. Metaclad, the Supreme Court of British Columbia found the tribunal to have exceeded its jurisdiction since "transparency" was not part of customary international law and the award was consequently partially set aside. ${ }^{60}$ National courts can investigate the reasoning and basis of a conclusion arrived at in an award even when the issue relates to international law.

Awards whose subject-matter cannot be resolved through arbitration, will not be enforced by the national court on the ground of non-arbitrability. Normally, disputes regarding the grant of intellectual property rights or competition are non-arbitrable. ${ }^{61}$ The determination of arbitrability is made by national courts based on national legislation and jurisprudence. In investment arbitration, disputes involve a mix of public and private interests. This raises the possibility of invoking non-arbitrability. ${ }^{62}$ The inevitable consequence is a larger role for national courts.

Public policy is that plain expansive ground leaving extensive discretion to the national court enforcing the award. ${ }^{63}$ All depends upon the approach the national court in question takes. An investment award could be challenged on the ground of violation of public policy of the state where enforcement proceedings are underway. ${ }^{64}$ Even where another court has enforced an award, a national court can consider the validity of the award under its own national laws. ${ }^{65}$

National courts have shown a high degree of deference to the conclusions of investment tribunals but do not generally decline jurisdiction to entertain the challenge ${ }^{66}$ National courts have undertaken broad assessments of awards at the stage of enforcement. Although theirs is not an appellate review, they have adopted liberal standards of review. ${ }^{67}$ A national court may review whether the interpretation of an investment tribunal accords with international law or with the national law of another state that is relevant to the dispute. In the Yukos case, The Hague District Court found that the conclusions of the arbitral tribunal on the provisional application of the Energy Charter Treaty (ECT) was incorrect. The court found the investment tribunal to have committed an error regarding the "context" in which the ECT was to

\footnotetext{
${ }^{59}$ Attorney General of Canada v. SD Myers, Federal Court of Canada, 13 January 2004, p. 21.

${ }^{60}$ Mexico v. Metaclad, Judgment of the Supreme Court of British Columbia, 2 May 2001, paras 70, $76,79$.

${ }^{61}$ Blackaby et al. (2015), p. 19.

${ }^{62}$ Reinisch (2010), pp. 678-679.

${ }^{63}$ Anatolie Stati, Gabriel Stati, Ascom Group SA and Terra Raf Trans Traiding Ltd v. Kazakhstan, SCC Case No. V 116/2010, Judgment of the UK Commercial Court on the Enforcement of the Award, 6 June 2017, para. 87.

${ }^{64}$ Poland v. Saar Papier Vertriebs GmbH, Swiss Federal Court, 20 September 2000, para. 3.b (paraphrased translation in Hobér and Eliasson (2010), p. 641).

${ }^{65}$ Anatolie Stati, Gabriel Stati, Ascom Group SA and Terra Raf Trans Traiding Ltd v. Kazakhstan, SCC Case No. V 116/2010, Judgment of the UK Commercial Court on the Enforcement of the Award, 6 June 2017, paras 92-93.

${ }^{66}$ Hobér and Eliasson (2010), pp. 668-669.

${ }^{67}$ Poland v. Saar Papier Vertriebs GmbH, Swiss Federal Court, 20 September 2000, para. 4.a (araphrased translation in Hobér and Eliasson (2010), p. 640).
} 
be interpreted ${ }^{68}$ and the object and purpose of the ECT and the nature of international law. ${ }^{69}$ Additionally, since the Russian Federation had not yet ratified the Energy Charter Treaty and the Russian laws and Constitution do not consider a treaty as binding unless ratified, it did not have any effect. The court embarked upon an interpretation of Russian law to find that the investment tribunal was in error. The court reasoned that Article 45 of the ECT allowed provisional application to the extent that the treaty is not contrary to national law. Russian national law did not permit arbitration of investment disputes. ${ }^{70}$ Hence, the dispute resolution provisions of the ECT would not be applicable and the investment tribunal did not have jurisdiction. ${ }^{71}$ In situations where the error goes to the determination of whether the dispute falls within the jurisdiction of an investment tribunal, the national court can arrive at a different conclusion than the tribunal and set aside an award.

The practice of national courts is diverse and, in some cases, they have exercised broad discretion while reviewing investment arbitration awards. The level of interference with substantive issues of law will be based on the position of the national law and the approach of the national court. In the Dutch legal system, as in many other jurisdictions, foreign law is treated as a question of law ${ }^{72}$ rather than as a question of fact. This inevitably gives greater latitude to the court to interpret foreign law. Even in jurisdictions where national law is treated as a question of fact, the national court could receive expert evidence and interpret and apply foreign law. ${ }^{73}$

Presence of an additional layer of regional courts could impede enforcement. ${ }^{74}$ Though not strictly national courts, they are regional in nature and do impact investment arbitration as actors. In the Achmea case, ${ }^{75}$ the Court of Justice of the European Union (CJEU) concluded that disputes arising from bilateral investment treaties between EU member states (intra-EU BITs) cannot be decided in investment arbitration since they involve interpretation of EU law, a function that is the monopoly of the CJEU. ${ }^{76}$ The case presents the possibility of arbitrability and

${ }^{68}$ Russian Federation v. Veteran Petroleum Ltd, The Hague District Court, Judgment, 20 April 2016, paras 5.12-5.13.

${ }^{69}$ Russian Federation v. Veteran Petroleum Ltd, The Hague District Court, Judgment, 20 April 2016, paras 5.19-5.20.

${ }^{70}$ Russian Federation v. Veteran Petroleum Ltd, The Hague District Court, Judgment, 20 April 2016, paras 5.33-5.34.

${ }^{71}$ Russian Federation v. Veteran Petroleum Ltd, The Hague District Court, Judgment, 20 April 2016, para. 5.96.

${ }^{72}$ Russian Federation v. Veteran Petroleum Ltd, The Hague District Court, Judgment, 20 April 2016, para. 5.34 .

${ }^{73}$ See Lazard Bros. v. Midland Bank [1933] A. C. 289, 297 (H. L. 1932) (United Kingdom); Gold v. Reinblatt, [1929] S.C.R. 74, [1939] I (United States); Re Low [1933] 2 DLR 608 (C.A.) (United States); Indian Evidence Act, 1872, s. 45.

${ }^{74}$ Reinisch (2010), p. 681.

${ }^{75}$ CJEU, Slovakia v. Achmea, Case C-284/16, ECLI:EU:C:2018:1.

${ }^{76} \mathrm{CJEU}$, Slovakia v. Achmea, Case C-284/16, ECLI:EU:C:2018:1, paras 53-59. 
mutual trust posing a challenge to enforcement of investment awards and reveals the role regional courts can play as actors in investment arbitration.

Involvement of multiple national courts and regional courts with their diverse jurisprudence allows them to affect investment arbitration in multiple and distinct ways. Even where actions of different national courts are not coordinated, they may influence arbitration proceedings and their outcome. In the Stati case, the investor succeeded in seeking enforcement in Sweden, the seat of arbitration, and in pursuing assets of the state in Belgium, Italy, Luxembourg, the Netherlands and the United States. ${ }^{77}$ The investor however had to withdraw from the proceedings in UK courts, where it was pursuing assets for enforcement, due to the fear of allegations of fraud being investigated by the UK Courts and the prospect of the award being set aside. ${ }^{78}$

\section{Actions of National Courts Challenged Before Investment Tribunals}

National courts are also actors in light of the fact that their conduct can be challenged before an investment tribunal. State responsibility for actions of national courts is attracted if national courts have violated a rule of international law. A host state may be responsible for failure to apply the New York Convention in good faith and thereby decline to enforce a commercial arbitration award. ${ }^{79}$ Actions of a national court may also result in denial of justice, a breach of fair and equitable treatment (FET), effective means, or indirect expropriation.

Even if within the internal constitutional structure of a state national courts are independent, their actions are attributable to the state and the state is responsible for the conduct of its national courts. ${ }^{80}$ Hitherto dormant, the customary rule of denial of justice has been invoked in investment arbitrations. ${ }^{81}$ It is inadequate for national courts to provide formal justice, i.e. avenues for redress but no real justice. The

\footnotetext{
${ }^{77}$ See Stati v. Kazakhstan: The winner takes it all?, Global Arbitration Review, 11 July 2018, https://globalarbitrationreview.com/article/1171805/stati-v-kazakhstan-the-winner-takes-it-all.

${ }^{78}$ Charlotin D, Stati and Ascom v. Kazakstan: UK Appeals Court allows claimants to avoid fraud trial, after they decide to abandon enforcement efforts in that jurisdiction, available at: https://www. iareporter.com/articles/stati-and-ascom-v-kazakhstan-uk-appeals-court-allows-claimants-to-avoidfraud-trial-after-they-decide-to-abandon-enforcement-efforts-in-that-jurisdiction/.

${ }^{79}$ Romak SA (Switzerland) v. Uzbekistan, PCA Case No. AA280, Award, 26 November 2009; Frontier Petroleum Services Ltd v. Czech Republic, PCA, Final Award, 12 November 2010; GEA Group Aktiengesellschaft v. Ukraine, ICSID Case No. ARB/08/16, Award, 31 March 2011; Saipem SpA v. Bangladesh, ICSID Case No. ARB/05/07, Award, 30 June 2009; White Industries Australia Limited v. India, UNCITRAL, Award, 30 November 2011; Desert Line Projects LLC v. Yemen, ICSID Case No. ARB/05/17, Award, 6 February 2008.

${ }^{80}$ Rajput (2018), pp. 148-149, 157-158.

${ }^{81}$ Paulsson (2005), pp. 38-56.
} 
standard of denial of justice requires the presence of a fair and functional judicial system. $^{82}$

Denial of justice will have to arise from the specific facts of the case in question and not from general perceptions about the functioning of the judiciary. ${ }^{83}$ The responsibility of a state for denial of justice for a decision of its national courts would not arise if a reader can follow its reasoning. ${ }^{84}$ Conversely, if the decision of a national court does not contain a reasoning that is logical and coherent, the decision may result in denial of justice. National courts are thus required to be careful in their reasoning and ensure that the proceedings are fair and so reflected in the record. The obligation of national courts is not to render a correct decision but only to adhere to fair procedures. ${ }^{85}$

Denial of justice is considered to be a part of fair and equitable treatment. Fair and equitable treatment functions as an independent standard for judging the actions of national courts. Legitimate expectations is a core element of FET, as developed in the jurisprudence of investment tribunals. In White Industries $v$. India, the tribunal rejected the investor's argument that there is a legitimate expectation of a certain judicial outcome. That case involved a certain desired interpretation of the New York Convention. ${ }^{86}$ In Tatneft $v$. Ukraine, the tribunal remarked in passing (obiter) that it would be a part of legitimate expectations that the legal framework in the host state is predictable and its organs, including the judiciary, function in a consistent manner. ${ }^{87}$ Consistency in decision-making is expected from national courts as a part of legitimate expectations.

A state is said to have violated the effective means standard if it fails to guarantee access to justice. ${ }^{88}$ National courts are expected to manage their caseload in a manner that prevents undue delays. Congestions in the court system resulting in undue delays could be treated as a breach of effective means. ${ }^{89}$ Interference from other branches, such as the executive, in judicial activity would be a breach of effective

\footnotetext{
${ }^{82}$ Paulsson (2005), pp. 60-61.

${ }^{83}$ Vannessa Ventures Ltd. v. Venezuela, ICSID Case No. ARB(AF)04/6, Award, 16 January 2013, para. 228; Swisslion DOO Skopje v. North Macedonia, ICSID Case No. ARB/09/16, Award, 6 July 2012, para 26.8; İçkale İşaat Limited Şirketi v. Turkmenistan, ICSID Case No. ARB/10/24, Award, 8 March 2016, para 8.1.10.

${ }^{84}$ Mr Franck Charles Arif v. Moldova, ICSID Case No. ARB/11/23, Award, 8 April 2013, paras. 481-482; Limited Liability Company Amto v. Ukraine, SCC Case No. 080/2005, Final Award, 26 March 2008, para 80.452-4.

${ }^{85}$ Paulsson (2005), pp. 81-82.

${ }^{86}$ White Industries Australia Limited v. India, UNCITRAL, Award, 30 November 2011, paras 10.3.13, 10.3.15.

${ }^{87}$ OAO Tatneft v. Ukraine, UNCITRAL, Award on Merits, 29 July 2014, para. 407.

${ }^{88}$ Duke Energy Electroquil Partners \& Electroquil SA v. Ecuador, ICSID Case No. ARB/04/19, Award, 18 August 2008, para 391.

${ }^{89}$ Chevron Corporation and Texaco Petroleum Corporation v. Ecuador, UNCITRAL, PCA Case No. 2009-23, Partial Award on Merits, 30 March 2010, paras 264-265; White Industries Australia Limited v. India, UNCITRAL, Award, 30 November 2011, paras 11.3.2, 11.4.14-15.
} 
means. ${ }^{90}$ The effective means test is seen as an effort by tribunals to expand treaty protection to cover judicial activity that would not be covered by denial of justice. Despite the concerns regarding the standard's scope, appropriateness and impact of effective means on the judicial activity of national courts, ${ }^{91}$ it remains a tool in the hands of investment tribunals to control the actions of national courts.

Situations where decisions of national courts result in loss of value of the investment have been treated as indirect expropriation. ${ }^{92}$ In Saipem v. Bangladesh, the tribunal considered that a decision of national courts not to enforce a commercial arbitration award is an expropriation of the right to arbitrate and of the outcome of that arbitration proceeding, that is, of "residual contractual rights under the investment as crystallized in the [commercial arbitration] award". 93 Tribunals have announced that they would not be reviewing decisions of national courts. But in effect, in cases involving non-enforcement of commercial arbitration awards by national courts, the tribunals have reviewed the decisions of national courts. ${ }^{94}$

In the absence of a BIT, actions of national courts could be challenged before an international court or tribunal on the ground of denial of justice, provided local remedies were exhausted and the home and host states expressed their agreement to refer the dispute to an international court or tribunal. BITs allow the foreign investor to raise the ground of denial of justice without the involvement of its home state. Denial of justice is a difficult standard to meet. Other standards, especially effective means and indirect expropriation, are less stringent and can be met relatively easily. The possibility of a potential challenge before an investment tribunal imposes restrictions on how national courts exercise jurisdiction.

\section{Conclusions}

Investment arbitration has contributed to the expansion of national courts' participation in matters of international law. National courts face issues relating to international investment law when it comes to facilitating arbitration, the enforcement of awards, or when their actions are challenged before investment tribunals. National courts and investment tribunals mutually influence each other.

National courts compete for jurisdiction with investment tribunals. Experience shows that they rarely manage to take over the jurisdiction of investment tribunals.

\footnotetext{
${ }^{90}$ Petrobart Limited v. Kyrgyz, Republic, SCC Case No. 126/2003, Arbitral Award, 29 March 2005, p. 77.

${ }^{91}$ Demirkol (2019), pp. 46-48.

${ }^{92}$ For a discussion of relevant cases, see Demirkol (2019), pp. 50-55.

${ }^{93}$ Saipem SpA v. Bangladesh, ICSID Case No. ARB/05/07, Award, 30 June 2009, paras 128, 130, 133.

${ }^{94}$ Saipem SpA v. Bangladesh, ICSID Case No. ARB/05/07, Award, 30 June 2009, para. 155; White Industries Australia Limited v. India, UNCITRAL, Award, 30 November 2011, paras. 10-4.1710.4.22.
} 
The ultimate word is with investment tribunals and they may leave some aspects of the investment dispute for national courts or they may take it over entirely. Even when some aspects of the dispute are left for national courts, those proceedings tend to be of nominal relevance only, since an investment award would comprehensively settle the dispute. National courts influence investment arbitration in various ways. As facilitators, national courts can be responsible for enforcing an investment arbitration award, they can even issue anti-suit injunctions, restraining a party from commencing proceedings before other national courts, or they can issue a pro-arbitration order. As a disruptive force, national courts can affect the commencement and continuation of proceedings through anti-arbitration injunctions or by setting aside an investment arbitration award.

The above discussion shows that the influence of national courts is rising since one of the parties, and especially states, frequently approach national courts. National courts have not shied away from exercising jurisdiction, although the standards they apply depend on the national law and legal culture of the state concerned. The growing involvement of national courts has increased the possibility of them influencing the functioning and outcome of investment arbitration.

The presence of national courts as an actor entails complications and uncertainties. Each national court functions differently and applies different rules and standards. It becomes difficult to conceptualise a unified framework of the involvement of national courts as actors. This is also an outcome of the discretion implicit in how national courts act in relation to investment arbitration. The involvement of national courts, due to the legal and cultural divergences of those jurisdictions, represents a plurality of approaches rather than a uniform overarching framework.

Finally, the role of national courts as actors in investment arbitration depends on the language of the BIT in question, but also on its interpretation and the general ideological orientation that a certain investment tribunal takes. There are no straitjacket-defined ways for national courts to become actors in investment arbitration. The extent of their intervention is conditioned on the interplay between the application of national and international law.

\section{References}

Blackaby N et al (2015) Redfern and Hunter on international arbitration. Oxford, p 19

Brownlie I (2003) Principles of public international law. Oxford, pp 38-40

Demirkol B (2019) Judicial acts and investment treaty arbitration. Cambridge, pp 46-48

Gill R (2009) ICSID provisional measures to enjoin parallel domestic litigation. World Arbitr Mediation Rev 535(3):553-564

Harisankar KS (2015) Annulment versus enforcement of international arbitral awards: does the New York Convention permit issue estoppel? Int Arbitr Law Rev 47

Hobér K, Eliasson N (2010) Review of investment treaty awards by municipal courts. In: Yanacca $\mathrm{K}$ (ed) Small, arbitration under international investment agreements: a guide to the key issues. Oxford, pp 668-669

Kjos HE (2013) Applicable law in investor-state arbitration: the interplay between national and international law. Oxford University Press 
Lew JDM (2008) Does national court involvement undermine the international arbitration process? ICSID Rev - FILJ 260(23):276-280, 287

Nollkaemper A (2006) The role of domestic courts in the case law of the International Court of Justice. Chin J Int Law 5:301-303, 312-321

Paulsson J (2005) Denial of justice in international law. Cambridge, pp 38-56

Rajput A (2018) Protection of foreign investment in India and investment treaty arbitration. Wolters Kluwer, pp 148-149, 157-158

Reinisch A (2010) Enforcement of investment awards. In: Yanacca K (ed) Small, arbitration under international investment agreements: a guide to the key issues. Oxford, pp 678-679

Rozas F (2005) Anti-suit injunctions issued by national courts: measures addressed to the parties or to the arbitrators. In: Gaillard E (ed) Anti-suit injunctions in international arbitration. IAI Series No. 2. Juris Publishing, pp 79-80

Sasson M (2017) Substantive law in investment treaty arbitration: the unsettled relationship between international law and municipal law, 2nd edn. Wolters Kluwer

Schreuer C (2009) ICSID convention: a commentary. Cambridge, pp 4-5

Schwebel S (2005) Anti-suit injunctions in international arbitration - an overview. In: Gaillard E (ed) Anti-suit injunctions in international arbitration. IAI Series No. 2. Juris Publishing, pp 5-6

Weil P (1992) Le droit international en quête de son identité: Cours générale de droit international public. Recueil des Cours 237:146-147

Yotova R (2017) Challenges in the identification of the "general principles of law recognized by civilized nations": the approach of the International Court of Justice. Can J Comp Contemp Law 269(3):298

Aniruddha Rajput is a Member of the United Nations International Law Commission (2017-2021). He served as the Chairperson of the Drafting Committee of the International Law Commission at its 69th Session in 2017. The topic proposed by him 'Evidence before International Courts and Tribunals' was put on the Long Term Programme of Work of the Commission in 2017. He advises and appears on behalf of states and private entities before international courts and tribunals and currently practices as a Consultant, Public International Law and International Arbitration, at Withers LLP in London. His areas of research and practice are general international law, the law of the sea, boundary disputes, international trade, and investment law. He has published and lectured in these areas. He has previously been Visiting Fellow at the Max Planck Institute Luxembourg for International, European and Regulatory Procedural Law (2019-2020) and Practitioner-in-residence at the KFG International Rule of Law - Rise of Decline? at Humboldt Universit, Berlin (2017).

Open Access This chapter is licensed under the terms of the Creative Commons Attribution 4.0 International License (http://creativecommons.org/licenses/by/4.0/), which permits use, sharing, adaptation, distribution and reproduction in any medium or format, as long as you give appropriate credit to the original author(s) and the source, provide a link to the Creative Commons license and indicate if changes were made.

The images or other third party material in this chapter are included in the chapter's Creative Commons license, unless indicated otherwise in a credit line to the material. If material is not included in the chapter's Creative Commons license and your intended use is not permitted by statutory regulation or exceeds the permitted use, you will need to obtain permission directly from the copyright holder.

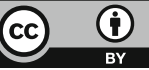

